\title{
Article
}

\section{Selective conversion of methanol to propylene over highly dealuminated mordenite: Al location and crystal morphology effects}

\author{
Li Ren, Bowen Wang, Kun Lu, Rusi Peng, Yejun Guan\#, Jin-gang Jiang, Hao Xu \$, Peng Wu* \\ Shanghai Key Laboratory of Green Chemistry and Chemical Process, School of Chemistry and Molecular Engineering, East China Normal University, \\ Shanghai 200062, China
}

\section{A R T I C L E I N F O}

\section{Article history:}

Received 5 September 2020

Accepted 10 October 2020

Available online 5 March 2021

\section{Keywords:}

Mordenite

Methanol to propylene

Dealumination

Al location

Crystal size

\begin{abstract}
A B S T R A C T
The growing consumption of light olefins has stimulated intensive researches on methanol to olefin (MTO) process which possesses great advantages for coal conversion to value-added chemicals in an environmentally benign way. The catalysts commonly used for MTO process faces several challenges such as poor selectivity control, low hydrothermal stability and short lifetime. In the present study, we prepared a series of mordenite zeolites with variable Al contents ( $\mathrm{Si} / \mathrm{Al}$ molar ratios of 51-436) by a sequential dealumination treatment of air-calcination and acid leaching. The textural properties, acidity and $\mathrm{Al}$ location before and after the dealumination treatment have been systematically studied and their effect on MTO especially the methanol to propylene (MTP) performance was thoroughly investigated. The mordenite zeolites with the Si/Al ratios over 150 selectively catalyzed methanol conversion in the MTP pathway, providing a high propylene selectivity of $63 \%$ and propylene/ethylene ratio of $>10$. Compared to the low-silica MOR catalysts, highly dealuminated MOR showed much higher stability and longer lifetime, which can be further enhanced via harsh hydrothermal pretreatment. Furthermore, the lifetime was highly related to the crystal size along $c$-axis. The excellent performance of highly dealuminated MOR is likely ascribed to the mesopores formed upon dealumination and the scarce $\mathrm{Al}$ sites located in the $\mathrm{T}$ sites shared by the 8-member ring (MR) side pockets and 12-MR pore channels.
\end{abstract}

(C) 2021, Dalian Institute of Chemical Physics, Chinese Academy of Sciences. Published by Elsevier B.V. All rights reserved.

\section{Introduction}

The growing economy aroused an increasing demand of light olefins, which are typically produced by steam cracking of naphtha and fluid catalytic cracking. In recent years, the global shortage of oil production has stimulated extensive researches on producing light olefin from non-oil resources. In this regard, developing coal to olefins via methanol intermediate, that is methanol to olefins (MTO) process, has attracted significant interests worldwide. Nowadays, this process has been successfully industrialized using zeolites as the catalysts $[1,2]$. Among the olefin products of MTO process, the production of propylene, that is, methanol to propylene (MTP) pathway, is more desired due to its growing consumption. It is generally accepted that the MTO reaction follows the dual cycle mechanism [3], namely the olefins-based and aromatics-based cycles.

\footnotetext{
* Corresponding author. Tel/Fax: +86-21-62232292; E-mail: pwu@chem.ecnu.edu.cn

\# Corresponding author. E-mail: yjguan@chem.ecnu.edu.cn

\$Corresponding author. E-mail: hxu@chem.ecnu.edu.cn

This work was supported by the Ministry of Science and Technology of the People's Republic of China (2016YFA0202804), the National Natural Science Foundation of China (21533002, 21872052, 21972044), and the Fundamental Research Funds for the Central Universities.

DOI: 10.1016/S1872-2067(20)63726-3 | http://www.sciencedirect.com/journal/chinese-journal-of-catalysis | Chin. J. Catal., Vol. 42, No. 7, July 2021
} 
The former one tends to generate propylene and higher olefins, while the latter one mainly leads to the formation of ethylene $\left(\mathrm{C}_{2}=\right)$ or propylene $\left(\mathrm{C}_{3}=\right)$, depending on the structure of multi-methyl benzenes formed inside zeolite pores [3-7], which closely related to the pore structures of zeolite catalysts [8-13].

For instance, the aromatics-based cycle involving polymethylbenzenes (PMBs) confined in the cavities of SAPO-34 leads to over $80 \%$ selectivity of $\mathrm{C}_{2}=$ and $\mathrm{C}_{3}=$, with ethylene as the main product, having a selectivity of $~ 50 \%[14,15]$. The size of cages and 8-member ring (MR) pores in SAPO catalysts play an essential role in determining the product distribution. Recently, SAPO-14, with AFN topology and consisted of narrower 8-MR pores and ultra-small cages, has been reported to show propylene selectivity as high as $77.3 \%$ in spite of fast deactivation [16]. However, numerous reports revealed that the MTP process takes place more readily on zeolites with larger pores, such as 10- or 12-MR pore channels [17-26]. In the case of ZSM-5 zeolite with three-dimensional (3D) 10-MR medium pore channels, propylene is preferentially produced with the selectivity of $\sim 35 \%$. Even higher propylene selectivity of $\sim 50 \%$ can be achieved by further reducing the acid site density and changing the morphology of ZSM-5 crystals through enhancing the olefins-based cycle [17-20]. Similarly, Beta zeolite with 3D 12-MR large-pore system and low Si/Al ratio of $\sim 25$ also produces mainly $\mathrm{C}_{3}=\mathrm{C}_{4}=$ and aromatic products owing to the aromatics-based cycle, but suffers fast deactivation due to the coke deposition $[21,22]$. The propylene selectivity and lifetime of Beta zeolites can be improved by increasing the $\mathrm{Si} / \mathrm{Al}$ ratio $[23,24]$. The lower acid density of high-silica Beta zeolites suppresses the hydrogen transfer reaction, thereby favoring the olefins-based cycles [25]. Other high-silica large-pore zeolites such as $\mathrm{CON}(\mathrm{Si} / \mathrm{Al}>100)$ also exhibits high propylene selectivity (60\%) and good stability in the MTP reaction [26].

Mordenite (MOR), as a large-pore zeolite, is composed of 12-MR and 8-MR pore channels running parallel along $c$-axis, which are interconnected by 8-MR side pockets along $b$-axis. MOR zeolite is well-known to be hydrothermally stable even after severe acid treatment, high temperature heating or steaming. Thus, the catalytic performance of mordenite zeolite in MTO process has been studied since 1980s [27]. Unfortunately, earlier studies reported that mordenite showed poor durability in MTO process because of strong acidity-related coke formation, especially for those with low $\mathrm{Si} / \mathrm{Al}$ ratios [27-30]. Conventionally synthesized mordenite is generally in aluminum-rich composition with $\mathrm{Si} / \mathrm{Al}$ ratio $<10$ [31], thus leading to poor catalytic performance in MTO reaction. It remains a great challenge to directly synthesize ultra-high silica mordenite zeolite [32,33]. Dealumination, conducted by acid-leaching, dry heating/steaming, or their combination, is then taken as a simple and efficient way to remove framework $\mathrm{Al}$ atoms [34]. Recently, Seo et al. [35] evaluated the catalytic performance of dealuminated MOR $(\mathrm{Si} / \mathrm{Al}=103)$ in the MTO reaction, achieving the propylene yield of $\sim 37 \%$. Although the lifetime and propylene selectivity were improved compared with the MOR sample with low $\mathrm{Si} / \mathrm{Al}$ ratio, even higher performance is still worth pursuing. Considering the excellent MTP perfor- mance over the zeolites with ultra-high $\mathrm{Si} / \mathrm{Al}>200$, such as ZSM-5, Beta and CON [17-26], the MTP performance of highly dealumianted MOR ( $\mathrm{Si} / \mathrm{Al}>200$ ) is reasonably expected to be superior, and the reaction mechanism may also change with the increase of $\mathrm{Si} / \mathrm{Al}$ ratios. Herein, we prepared highly siliceous mordenites with $\mathrm{Si} / \mathrm{Al}$ ratios in a wide range of $50-440$ via dealumination process and explored their catalytic performance and durability in MTP process. The effect of dealumination on the textural properties, Al distribution and reaction pathway was carefully studied. The MOR catalyst with a Si/Al ratio close to 300 showed the best MTP performance benefiting from the newly formed mesopores and highly optimized Brønsted acid distribution.

\section{Experimental}

\subsection{Materials preparation}

The mordenite sample with the Si/Al molar ratio of 6 and crystal size of $\sim 200 \mathrm{~nm}$ (denoted as M-200(6)) was purchased from Zhejiang Taide New Material Co., Ltd. China. The dealuminated MOR samples with various $\mathrm{Si} / \mathrm{Al}$ ratios were obtained by changing the calcination and acid treatment conditions and denoted as $\mathrm{M}-200(x)$, wherein $x$ is the $\mathrm{Si} / \mathrm{Al}$ ratio determined by ICP analysis. Firstly, the M-200(6) was calcined at high temperatures (873-1023 K). Then the calcined M-200(6) sample was refluxed in $\mathrm{HNO}_{3}$ solution for several hours. The acid-treated material was filtrated, washed with deionized water, dried at $353 \mathrm{~K}$ overnight and calcined at $773 \mathrm{~K}$ for $5 \mathrm{~h}$. The detailed dealumination conditions are listed in Table S1. For comparison, two another MOR zeolites with the crystal size of $\sim 400 \mathrm{~nm}(\mathrm{M}-400)$ and $\sim 50 \mathrm{~nm}(\mathrm{M}-50)$ were also used in the present study, and they were obtained from Zhejiang Taide New Material Co., Ltd. and Shanghai Jiao Tong University, respectively. The framework $\mathrm{Si} / \mathrm{Al}$ ratio was also enhanced via dealumination to produce the corresponding high-silica samples of M-400(190) and M-50(154), and the dealumination condition were also summarized in Table S1. A rod-like mordenite denoted as M-R was hydrothermally synthesized according to the process mentioned in the literature [36]. In a typical synthesis, sodium hydroxide (96 wt\%), sodium aluminate (44.15 wt $\% \mathrm{Al}_{2} \mathrm{O}_{3}, 36.08 \mathrm{wt} \% \mathrm{Na}_{2} \mathrm{O}$ ) and silica gel (95.0 wt $\% \mathrm{SiO}_{2}$, 5.0 wt $\% \mathrm{H}_{2} \mathrm{O}$, Qingdao Haiyang Chemical Co., Ltd.) were successively added into the deionized water. The solution was stirred vigorously to form a homogeneous gel with the molar composition of $1 \mathrm{SiO}_{2}: 0.24 \mathrm{Na}_{2} \mathrm{O}: 0.067 \mathrm{Al}_{2} \mathrm{O}_{3}: 22 \mathrm{H}_{2} \mathrm{O}$. Then, $1 \mathrm{wt} \%$ mordenite seed (M-200) depending on the weight of $\mathrm{SiO}_{2}$ in the gel was added. The synthetic gel was crystallized in a Teflon-lined stainless-steel autoclave at $443 \mathrm{~K}$ for $24 \mathrm{~h}$ dynamically. The obtained M-R was first calcined at $973 \mathrm{~K}$ for $5 \mathrm{~h}$, and then refluxed in $\mathrm{HNO}_{3}(6 \mathrm{M})$ solution with a solid-to-liquid weight ratio of $1: 10$ at $413 \mathrm{~K}$ for $10 \mathrm{~h}$, giving rise to a dealuminated sample M-R(196) with a Si/Al ratio of 196.

\subsection{Characterization methods}

The powder X-ray diffraction (XRD) patterns were recorded 
on a Rigaku Ultima IV X-ray diffractometer with $\mathrm{Cu}-K_{\alpha}$ radiation $(\lambda=1.5405 \AA)$ at $35 \mathrm{kV}$ and $25 \mathrm{~mA}$. The images of the crystals were obtained by scanning electron microscopy (SEM) on a Hitachi S-4800 microscope and transmission electron microscopes (TEM) on a JEOL-JEM-2100 microscope. Inductively coupled plasma emission spectrometry (ICP) was carried out by using a thermal IRIS Intrepid XSP atomic emission spectrometer to quantify the amounts of $\mathrm{Si}$ and $\mathrm{Al}$ in the samples. The textural properties of the samples were determined by $\mathrm{N}_{2}$ sorption isotherms at $77 \mathrm{~K}$ taken on a BELSORP-MAX instrument equipped after activating the samples at $573 \mathrm{~K}$ for $5 \mathrm{~h}$ under vacuum conditions. The Brunauer-Emmett-Teller (BET) equation was used to calculate the total surface area. The $t$-plot method was used to evaluate the micropore volume, micropore surface area and external surface area. On the other hand, $\mathrm{Ar}$ sorption measurments were carried out at $87 \mathrm{~K}$ on a Micromeritics ASAP 2020 instrument, the pore size distribution was calculated with Horvath-Kawazoe method. The ${ }^{27} \mathrm{Al}$ MAS NMR spectra were collected on a VARIAN VNMRS-400WB NMR spectrometer. The temperature programmed adsorption of ammonia ( $\mathrm{NH}_{3}$-TPD) was recorded on Micromeritics $\mathrm{Au}$ toChem II to measure the acidity. The sample was pretreated at $823 \mathrm{~K}$ for $60 \mathrm{~min}$ in a helium flow, and then exposed to ammonia at $353 \mathrm{~K}$ for certain period. Before the desorption test, the physisorbed ammonia was removed by helium. Lastly, the sample was heated from 353 to $1073 \mathrm{~K}$ at a ramping rate of 10 $\mathrm{K} \mathrm{min}^{-1}$. Thermogravimetry (TG) analysis were performed on a TGA/DSC 3+ instrument in an air flow of $50 \mathrm{~mL} \mathrm{~min}^{-1}$ with a ramping rate of $5 \mathrm{~K} \mathrm{~min}^{-1}$. The FTIR spectra were collected on Nicolet Nexus 670 FTIR spectrometer with the resolution of 4 $\mathrm{cm}^{-1}$. First, a wafer pressed with $20 \mathrm{mg}$ powder sample was placed in a quartz cell sealed with $\mathrm{CaF}_{2}$ windows. After evacuated at $823 \mathrm{~K}$ for $2 \mathrm{~h}$, the FTIR spectra in the $v(\mathrm{O}-\mathrm{H})$ region was recorded at room temperature. The sample was then exposed to $\mathrm{CD}_{3} \mathrm{CN}$ or pyridine vapor at $298 \mathrm{~K}$ for $20 \mathrm{~min}$. Subsequently, the IR spectra was collected at different desorption temperatures (323-573 K) by keeping both the ramping and plateau step for $5 \mathrm{~min}$.

\subsection{Catalytic performance in the methanol to propylene (MTP) reaction}

The MTP reaction was performed in a fixed-bed at atmospheric pressure. $0.1 \mathrm{~g}$ of zeolite pellets without a binder (20-60 mesh) was activated in $\mathrm{N}_{2}$ at $773 \mathrm{~K}$ for $1 \mathrm{~h}$ before the reaction. The liquid-phase methanol was then introduced into the quartz reactor (internal diameter of $8 \mathrm{~mm}$ ) by a microfeeder at a weight hourly space velocity (WHSV) of $1 \mathrm{~h}^{-1}$ and the $\mathrm{N}_{2}$ flow was maintained at $20 \mathrm{~mL} / \mathrm{min}$. The effluent products and reactant were analyzed by an online Tianmei GC7900 equipped with a HP-PLOT/Q capillary column (30 m × $0.32 \mathrm{~mm} \times 20 \mu \mathrm{m})$ and a FID detector. When calculating the conversion, the dimethyl ether was calculated as the reactant. To explore the role of Al location in MTP reaction, pyridine/methanol solution with pyridine concentration of $1300 \mathrm{ppm}$ was used as the reactant. The pre-hydrothermal treatment of $\mathrm{M}-200(274)$ was performed by introducing the mixture flow of $\mathrm{N}_{2}$ and $\mathrm{H}_{2} \mathrm{O}\left(\mathrm{N}_{2}: 5\right.$
$\mathrm{mL} / \mathrm{min}, \mathrm{N}_{2} / \mathrm{H}_{2} \mathrm{O}=1 / 9$ ) at $873 \mathrm{~K}$ for $6 \mathrm{~h}$, followed by a calcination at $773 \mathrm{~K}$ for $5 \mathrm{~h}$. The M-200(274) after hydrothermal treatment was denoted as M-200(274)-HT.

The retained hydrocarbons in the spent catalysts were analyzed according to the literature [23,24]. $100 \mathrm{mg}$ of the spent catalyst was directly dissolved in $1 \mathrm{~mL} 40 \mathrm{wt} \% \mathrm{HF}$ solution and $1 \mathrm{~mL}$ of $\mathrm{CH}_{2} \mathrm{Cl}_{2}$ was added to extract the organic species. To further determine the location of coke, the two-step extraction process was performed. $100 \mathrm{mg}$ of the spent sample was immersed in $1 \mathrm{~mL} \mathrm{CH} \mathrm{Cl}_{2}$ under ultrasonic for $10 \mathrm{~min}$, then the organic solution which contained the organic species located on the surface and pore mouth was separated by centrifugation. The sample was further washed with $\mathrm{CH}_{2} \mathrm{Cl}_{2}$, followed by being dissolved in $40 \% \mathrm{HF}$ solution ( $1 \mathrm{~mL}$ ), and the residual organic species in the micropores were extracted by $1 \mathrm{~mL}$ $\mathrm{CH}_{2} \mathrm{Cl}_{2}$. The organic compounds were qualitatively identified on a GC-MS (Agilent 7890B/5977A GC/MSD) equipped with a HP-5 capillary column.

\section{Results and discussion}

\subsection{Textural properties of the pristine and dealuminated M-200 samples}

Fig. 1 shows the XRD patterns of the pristine M-200(6) as well as the acid-treated samples with various $\mathrm{Si} / \mathrm{Al}$ ratios obtained under different dealumination conditions as listed in Table S1. All the samples exhibited typical diffraction peaks ascribed to the MOR topology, and these peaks became more intense with the increase of the $\mathrm{Si} / \mathrm{Al}$ ratio, which was similar to the previous literature [37]. Table 1 lists the surface area, pore volume and $\mathrm{Si} / \mathrm{Al}$ ratio of the pristine $\mathrm{M}-200(6)$ zeolite and the dealuminated ones, determined by $\mathrm{N}_{2}$ sorption isotherms (Fig. S1) and ICP analysis, respectively. The total surface area and pore volume of the parent M-200(6) zeolite were 494 $\mathrm{m}^{2} \mathrm{~g}^{-1}$ and $0.27 \mathrm{~cm}^{3} \mathrm{~g}^{-1}$, respectively. The dealumination process significantly enhanced the external surface area and mesopore volume due to the formation of mesopores, indicated by the multilayer adsorption behaviors and hysteresis loops in $\mathrm{N}_{2}$ sorption isotherms (Fig. S1). For instance, the external surface

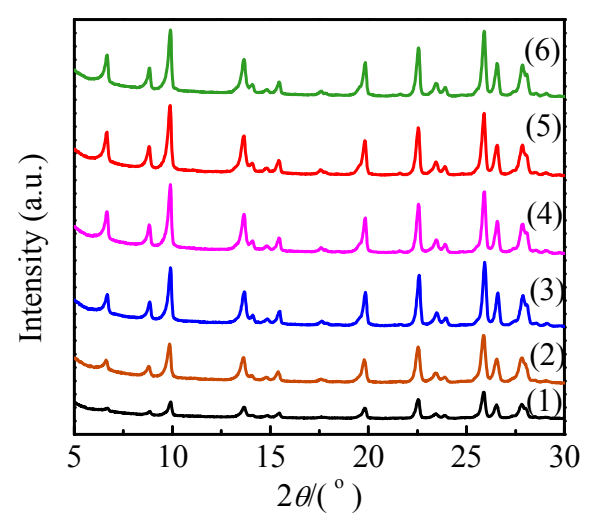

Fig. 1. XRD patterns of the M-200 samples with different $\mathrm{Si} / \mathrm{Al}$ ratios. (1) M-200(6); (2) M-200(51); (3) M-200(98); (4) M-200(171); (5) $\mathrm{M}-200(274)$; (6) M-200(436). The numbers in parentheses indicate the $\mathrm{Si} / \mathrm{Al}$ atomic ratios, the same below. 
Table 1

Textural properties of various M-200 samples.

\begin{tabular}{|c|c|c|c|c|c|c|c|}
\hline \multirow{2}{*}{ Sample } & \multirow{2}{*}{$\mathrm{Si} / \mathrm{Al}$ ratio } & \multicolumn{3}{|c|}{ Surface area $\left(\mathrm{m}^{2} \mathrm{~g}^{-1}\right)$} & \multicolumn{3}{|c|}{ Pore volume $\left(\mathrm{cm}^{3} \mathrm{~g}^{-1}\right)$} \\
\hline & & $S_{\text {total }^{a}}$ & $S_{\text {micro }}{ }^{b}$ & $S_{\text {ext }^{\mathrm{c}}}^{\mathrm{c}}$ & $V_{\text {total }^{\mathrm{d}}}$ & $V_{\text {micro }}{ }^{\mathrm{b}}$ & $V_{\text {meso }} \mathrm{e}^{\mathrm{e}}$ \\
\hline $\mathrm{M}-200(6)$ & 6 & 494 & 481 & 13 & 0.27 & 0.19 & 0.08 \\
\hline$M-200(51)$ & 51 & 496 & 446 & 50 & 0.30 & 0.18 & 0.12 \\
\hline$M-200(98)$ & 98 & 493 & 445 & 48 & 0.32 & 0.18 & 0.14 \\
\hline $\mathrm{M}-200(171)$ & 171 & 526 & 463 & 63 & 0.36 & 0.18 & 0.18 \\
\hline$M-200(274)$ & 274 & 525 & 477 & 48 & 0.35 & 0.19 & 0.16 \\
\hline$M-200(436)$ & 436 & 525 & 477 & 48 & 0.34 & 0.19 & 0.15 \\
\hline
\end{tabular}

a Calculated by BET method.

${ }^{b}$ Calculated by $t$-plot method.

c $S_{\text {ext }}=S_{\text {total }}-S_{\text {micro. }}$

${ }^{\mathrm{d}}$ Determined from the adsorption capacity at $P / P_{0}=0.9$ at $77 \mathrm{~K}$.

e $V_{\text {meso }}=V_{\text {total }}-V_{\text {micro }}$.

area of M-200(171) reached $63 \mathrm{~m}^{2} \mathrm{~g}^{-1}$, which was 5 times of the parent $M-200(6)$ sample. The dealumination process increased the mesopore volume of M-200(6) from 0.08 to 0.18 $\mathrm{cm}^{3} \mathrm{~g}^{-1}$ for $\mathrm{M}-200(171)$. The effect of dealumination on the pore size was studied by Ar physisorption (Fig. S2). The pore size distribution curve of the pristine M-200(6) zeolite showed a peak centered at $0.588 \mathrm{~nm}$, attributed to the main 12-MR pores of the MOR topology. Although only minor changes were observed for the micropore volume of MOR after dealumination, the pore width was enlarged. M-200(51) sample showed a relatively broad peak centered at $0.594 \mathrm{~nm}$ due to the deformation of 12-MR pores after the preferential removal of $\mathrm{Al}$ atoms in Al-rich 4-MR units [38]. Further increasing the Si/Al ratio by severe dealumination, the broadening phenomenon disappeared due to the structural repairing by silicon insertion during dealumination [39].

The change of the Al species in the dealumination process was investigated by ${ }^{27} \mathrm{Al}$ MAS NMR spectroscopy (Fig. S3). $\mathrm{M}-200(6)$ gave two resonances at 55 and $0 \mathrm{ppm}$, assigned to tetrahedrally and octahedrally coordinated Al species, respectively [37]. The extra-framework $\mathrm{Al}$ atoms were successfully removed by nitric acid treatment according to the disappearance of the resonance band at $0 \mathrm{ppm}$. The morphology change during the dealumination was revealed by the SEM images (Fig. S4). M-200(6) consisting of the aggregates of irregular prism-like nanocrystals had the particle sizes ranging from 100 to $400 \mathrm{~nm}$. After dealumination, the nanocrystals were worn to show more smooth corners. Numerous randomly distributed light spots were observed in the TEM images of the dealuminated sample M-200(274) (Fig. S5), revealing the existence of intracrystal mesopores, which was in line with the $\mathrm{N}_{2}$ sorption results.

\subsection{Acid properties and the nature of Al species of dealuminated mordenite zeolites}

The catalytic activity of mordenite is closely related to the distribution of the $\mathrm{Al}$ atoms in four kinds of tetrahedral sites [40], i.e. T1-T4 as shown in Scheme 1(a). Several techniques have been developed to reveal the distribution of the $\mathrm{Al}$ atoms, among which the $\mathrm{OH}$ vibration and $\mathrm{CD}_{3} \mathrm{CN}$-adsorbed FTIR spectra are the most commonly used ones. Fig. S6 shows the IR spectra of various dealuminated M-200 samples in the $\mathrm{OH}$ vibration region of $3800-3400 \mathrm{~cm}^{-1}$. Three IR bands centered at 3745,3659 and $3610 \mathrm{~cm}^{-1}$, attributed to $\mathrm{OH}$ species bounded to the isolated external silanol, extra-framework aluminum species and bridging $\mathrm{Si}(\mathrm{OH}) \mathrm{Al}$ groups in framework, were observed for the pristine material. After dealumination, the band at $3659 \mathrm{~cm}^{-1}$ diminished, indicating that the extra-framework aluminum species were removed, in agreement with the results from ${ }^{27} \mathrm{Al}$ MAS NMR spectra. Meanwhile, the $3500 \mathrm{~cm}^{-1}$ band assigned to internal silanol nests appeared [41,42], due to the removal of framework $\mathrm{Al}$ atoms. The $3610 \mathrm{~cm}^{-1}$ band due to the bridging $\mathrm{Si}(\mathrm{OH}) \mathrm{Al}$ hydroxyl groups decreased significantly in

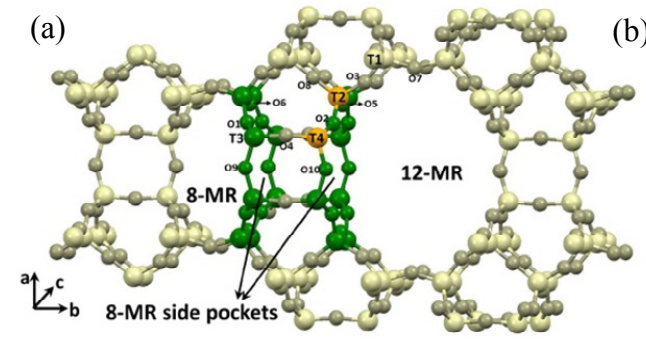

(b)

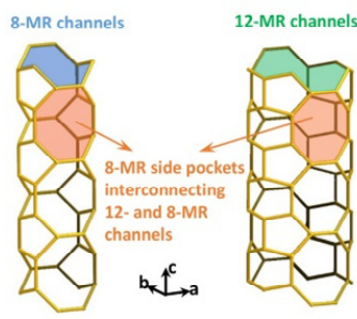

Scheme 1. (a) Mordenite (MOR topology) structure showing four tetrahedral atoms (T1-T4) and ten oxygen atoms (01-010) with different locations The main 12-MR channels and small 8-MR channels, parallelly running along the $c$-axis, are interconnected by 8-MR side pockets (marked in green and orange) along the $b$-axis. T1 is located in the junction of 8-MR and 12-MR pores, T2 and T4 are located in the intersection of 8-MR side pockets and 12-MR channels, while T3 is situate in the intersection of 8-MR side pockets and 8-MR channels, (b) 8-MR channels (marked in blue), 12-MR channels (marked in green) and the 8-MR side pockets interconnecting 12- and 8-MR channels (marked in orange) in the MOR structure. 

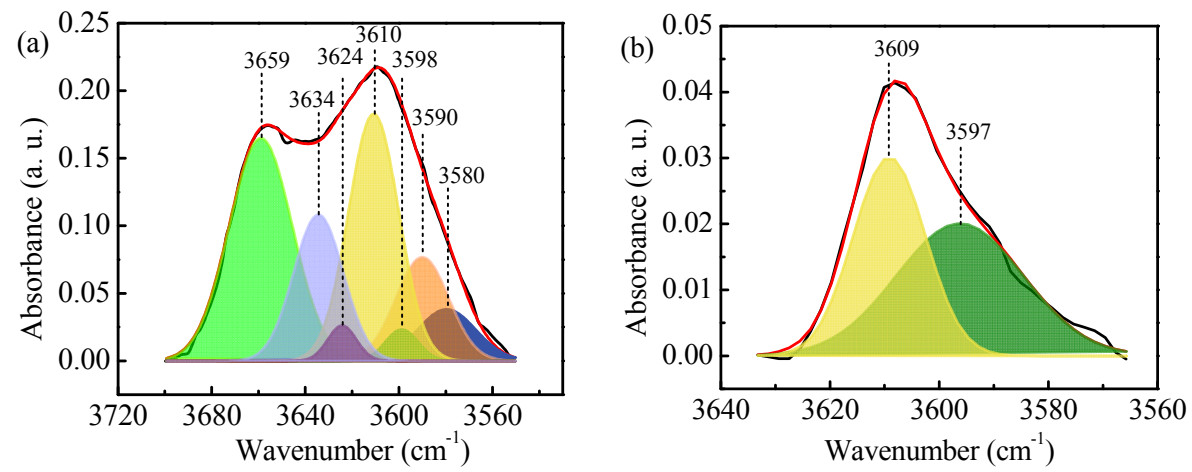

Fig. 2. Deconvoluted FTIR spectra of M-200(6) (A) and M-200(98) (B) in the OH vibration region.

intensity with increase of $\mathrm{Si} / \mathrm{Al}$ ratio, but still visible for M-200(274) with an extremely low Al content (Fig. S6(6)), implying the presence of framework Al species. Lukyanov and coworkers proposed that the $3610 \mathrm{~cm}^{-1}$ band could be deconvoluted into six components according to the heterogeneity of $\mathrm{Al}$ sites in MOR [43]. By adopting this method, we have deconvoluted the IR spectra in the $\mathrm{OH}$ vibration region for M-200(6) and M-200(98) and the results are shown in Fig. 2 and Table S2. It should be noted that we failed in deconvolution of the spectra of samples with higher $\mathrm{Si} / \mathrm{Al}$ ratios because the peak intensity was too weak. These bands could be classified into three pairs. The low-frequency bands (3580 and $3590 \mathrm{~cm}^{-1}$ ) are attributed to $01-\mathrm{H}$ and $09-\mathrm{H}$ bonded to T3 in the 8-MR side pockets. The high-frequency bands (3598 and $3610 \mathrm{~cm}^{-1}$ ) are assigned to at least two of three oxygen atoms (05-H, O2-H and 010-H), which are related to T2 and/or T4 sites in the 8-MR side pockets. The top-frequency bands ( 3624 and $3634 \mathrm{~cm}^{-1}$ ) are attributed to $03-\mathrm{H}$ and $07-\mathrm{H}$ linked to $\mathrm{T} 1$. After dealumina- tion, only two bands (3609 and $3597 \mathrm{~cm}^{-1}$ ) were observed in the deconvoluted spectrum of M-200(98) (Fig. 2(b)), suggesting that the $\mathrm{Al}$ atoms located in $\mathrm{T} 1$ and $\mathrm{T} 3$ sites were almost removed while some of $\mathrm{Al}$ atoms in the $\mathrm{T} 2$ and $\mathrm{T} 4$ sites were retained after dealumination. We thus speculate that the residual framework Al-related Brönsted acid sites (BAS) were mainly present in the intersection between 8-MR side pockets and 12-MR pore channels for the highly dealuminated samples ( $\mathrm{Si} / \mathrm{Al}>98)$.

To shed more light on Al location, $\mathrm{CD}_{3} \mathrm{CN}$ adsorbed FT-IR spectra were recorded on various M-200 samples (Fig. 3). There are four bands assigned to the stretching vibration of the $\mathrm{C} \equiv \mathrm{N}$ bond. The band around $2328 \mathrm{~cm}^{-1}$ is attributed to the adsorption of $\mathrm{CD}_{3} \mathrm{CN}$ on the Lewis acid sites. The bands at 2315 and $2277 \mathrm{~cm}^{-1}$ are ascribed to the $\mathrm{CD}_{3} \mathrm{CN}$ molecules interacting with acidic $\mathrm{Si}(\mathrm{OH}) \mathrm{Al}$ hydroxyl groups in the 8-MR side pockets. The $2297 \mathrm{~cm}^{-1}$ band is corresponding to $\mathrm{CD}_{3} \mathrm{CN}$ adsorbed in the 12-MR main pores of MOR zeolite [44]. Fig. 3 shows that the
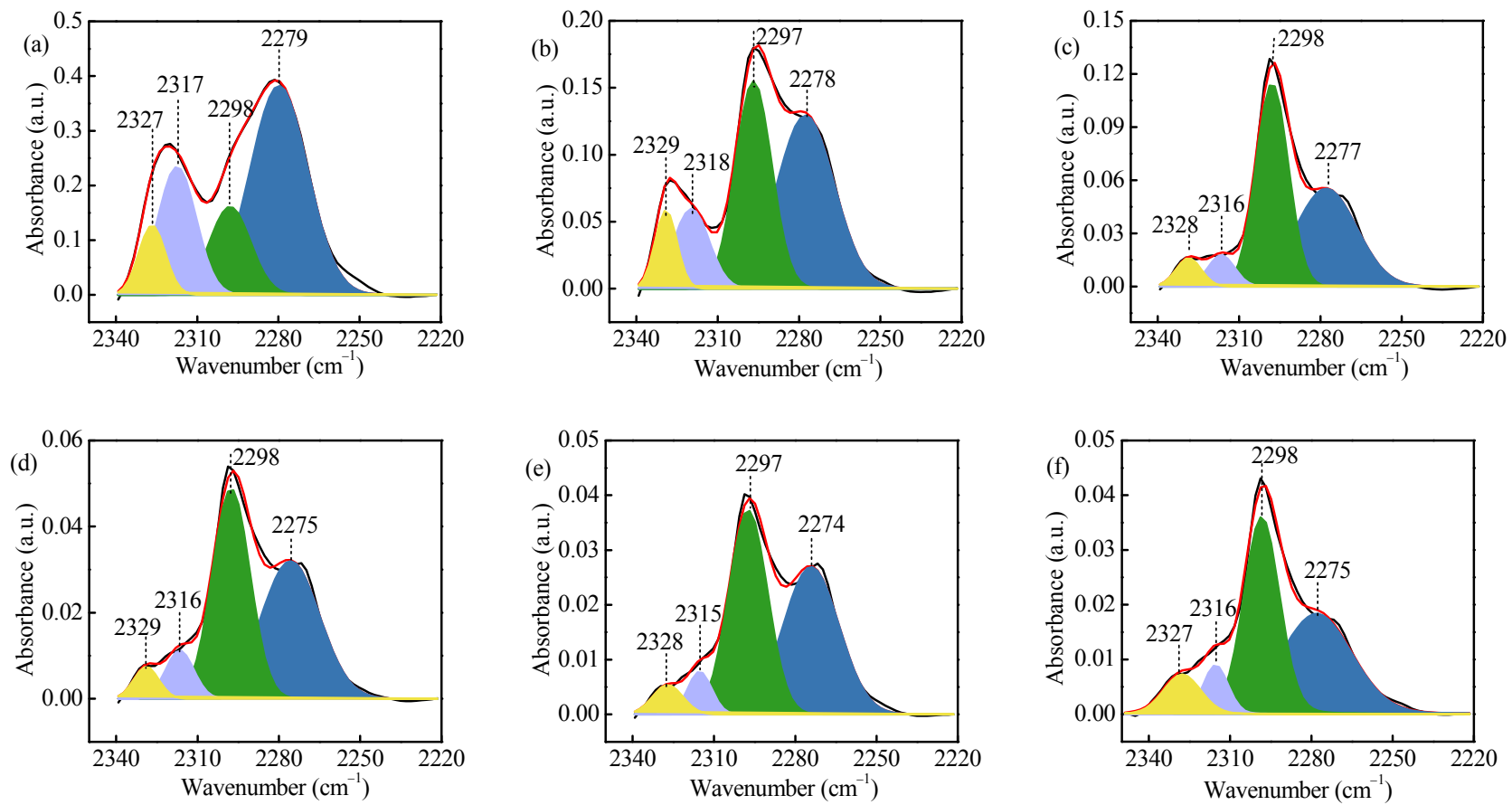

Fig. 3. $\mathrm{CD}_{3} \mathrm{CN}$ adsorbed FT-IR spectra of various M-200 samples at $423 \mathrm{~K}$. (a) M-200(6); (b) M-200(51); (c) M-200(98); (d) M-200(171); (e) M-200(274); (f) M-200(436). 


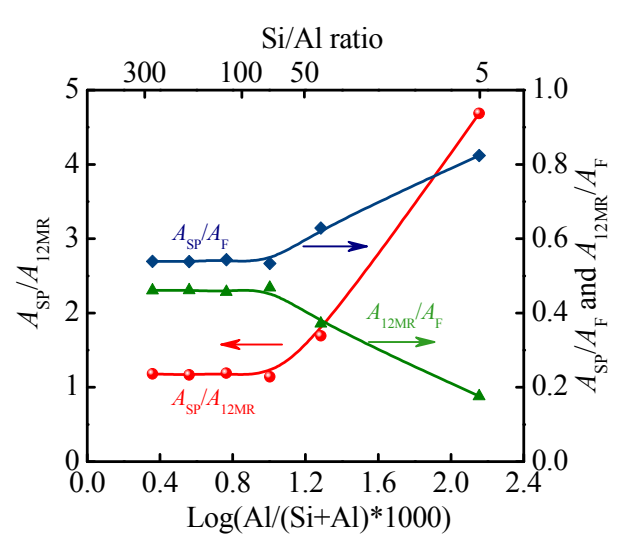

Fig. 4. The changes of relative $\mathrm{Al}$ distributions with the $\mathrm{Al}$ content. Asp: the sum area of the 2315 and $2277 \mathrm{~cm}^{-1}$ bands related to the $\mathrm{Al}$ ions in 8-MR side pockets; $A_{12 \mathrm{MR}}$ : the area of $2297 \mathrm{~cm}^{-1}$ band associated to the $\mathrm{Al}$ ions in 12-MR; $A_{\mathrm{F}}$ : the total area of 2277, 2297 and $2315 \mathrm{~cm}^{-1}$ bands assigned to the whole $\mathrm{Al}$ ions in framework.

intensity of all the adsorbed $\mathrm{CD}_{3} \mathrm{CN}$ related bands significantly decreased with the increase of $\mathrm{Si} / \mathrm{Al}$ ratio. It is worth noting that the ratio of $\mathrm{Al}$ atoms located in 12-MR to the total framework $\mathrm{Al}$ atoms $\left(A_{12 \mathrm{MR}} / A_{\mathrm{F}}\right)$ increased when the $\mathrm{Si} / \mathrm{Al}$ ratio increased from 6 to 98, while further decreasing the Al content, the $A_{12 \mathrm{MR}} / A_{\mathrm{F}}$ ratio kept constant (Fig. 4). The ratio of $\mathrm{Al}$ atoms located in 8-MR side pockets to those in 12-MR pores ( $\left.A_{\mathrm{SP}} / A_{12 \mathrm{MR}}\right)$ was as high as 4.6 for M-200(6), then dramatically decreased to 1 for M-200(98) after dealumination, indicating the dealumination process preferentially removed the $\mathrm{Al}$ atoms located in 8-MR side pockets. With the $\mathrm{Si} / \mathrm{Al}$ ratios higher than 98, the residual $\mathrm{Al}$ atoms mainly located in $\mathrm{T} 2$ and/or $\mathrm{T} 4$ sites as revealed by the $\mathrm{OH}$ vibration IR spectra (Fig. 2(b)), and they both contribute to the $A_{\mathrm{SP}}$ and $A_{12 \mathrm{Mr}}$. Thus, the $A_{\mathrm{SP}} / A_{12 \mathrm{Mr}}$ value was constant for the samples with $\mathrm{Si} / \mathrm{Al}$ ratio $>98$.

Compared with $\mathrm{CD}_{3} \mathrm{CN}$, pyridine (Py) is relatively larger in molecular size and it is another suitable probe molecule for characterizing the acidity via IR spectra (Fig. S7). The pyridine molecule is too big to enter the 8-MR pore channels of MOR along $c$-axis, implying the detectable acidity determined by the Py-adsorbed IR spectra was irrelevant to the acid sites located in 8-MR pore channels. The bands at 1454 and $1545 \mathrm{~cm}^{-1}$ are attributed to the vibrations of the pyridine molecules adsorbed on Lewis acid (LA) and Brönsted acid (BA) sites, respectively [45-47]. The band at $1490 \mathrm{~cm}^{-1}$ is contributed by both Lewis and Brønsted acid sites. The intensity of the three bands was reasonably weakened with the increase of the $\mathrm{Si} / \mathrm{Al}$ ratio. The band related to the LA sites $\left(1454 \mathrm{~cm}^{-1}\right)$ disappeared when the $\mathrm{Si} / \mathrm{Al}$ ratio reached 171 , while the $1545 \mathrm{~cm}^{-1}$ band related to the BA sites was still observed for the sample with a Si/Al ratio as high as 274 , although it was extremely weak in intensity. These results suggested that the Al-related BA sites still existed in the 12-MR pore channels after severe dealumination. Considering the results from $\mathrm{OH}$ vibration and $\mathrm{CD}_{3} \mathrm{CN}$-adsorbed IR spectra, these residual $\mathrm{Al}$ atoms in the 12 -MR pore channels should be the $\mathrm{T} 2$ and $\mathrm{T} 4 \mathrm{Al}$ atoms.

The strength and total amount of the acid sites in various MOR samples were further measured by $\mathrm{NH}_{3}$-TPD technique.
There were two desorption peaks around 423 and $723 \mathrm{~K}$ (Fig. S8), corresponding to the weak acid sites and strong acid sites, respectively. With the increase of $\mathrm{Si} / \mathrm{Al}$ ratio, the weak and strong acid sites both decreased in density. Niwa et al. proposed that the strength of Brönsted acid sites in the 8-MR pore channels was larger than that in 12-MR pores [48]. Both of the two desorption peaks shifted to lower temperature region, meaning that stronger acid sites located in 8-MR pore channels were preferentially removed. Combining the above characterization results, it could be concluded that the residual $\mathrm{Al}$ atoms mainly located in T2 and T4 sites shared by the 8-MR side pockets and the 12-MR pore channels for the highly dealuminated mordenites, showing weaker Brönsted acidity compared with the low-silica sample.

\subsection{Catalytic performance of MOR in MTP reaction}

\subsubsection{Effect of dealumination on the catalytic performance of MOR zeolites in the MTP reactions}

The catalytic performances of the pristine and dealuminated MOR samples in MTO reaction were compared under identical conditions. Fig. 5 displays the methanol conversion and product distribution of M-200(6) and M-200(274). The pristine M-200(6) catalyst showed an initial methanol conversion of $100 \%$ and quickly decreased to $7 \%$ at time on stream (TOS) of $2.2 \mathrm{~h}$ (Fig. 5(a)). After deep dealumination, the M-200(274) catalyst gave a methanol conversion of $>98 \%$ at the initial stage and the activity could last for $132 \mathrm{~h}$ by keeping the methanol conversion over $80 \%$. The catalytic performances of other MOR zeolites are also summarized in Fig. S9. The initial methanol conversion was slightly below $100 \%$ for these samples with $\mathrm{Si} / \mathrm{Al}>98$. While the stability of dealumianted MOR samples was enhanced with the increase of $\mathrm{Si} / \mathrm{Al}$ ratio from 51 to 274 . Further increasing the $\mathrm{Si} / \mathrm{Al}$ ratio to 436 resulted in worse stability (Fig. S9(d)), probably because of insufficient Al-related active sites. The spent catalysts were also characterized and the results are shown in Table S6. The BET surface area, micropore and mesopore volume all decreased after reaction. More severe blocking of the micropores was noticed for samples with low $\mathrm{Si} / \mathrm{Al}$ ratio. The micropore volume decreased by $78.9 \%$ for the M-200(6) catalyst, while only $\sim 38 \%$ was observed for the high-silica catalysts with $\mathrm{Si} / \mathrm{Al}>98$. The decrease of micropore volume could be ascribed to the deconstruction of zeolite framework or the coke deposition. As shown in Fig. S10(a), the MOR structures were well-preserved after the MTP reaction. The TG analysis of the spend catalysts showed that the low-silica MOR catalyst suffered more severe coke deposition than the high-silica one (Fig. S10(b)). This result strongly points to the catalyst deactivation was caused by coke deposition and those low-silica MOR catalysts with stronger acidity and larger acid amount suffered fast deactivation. The lifetime of M-200(274) catalyst could be further enhanced by performing a pre-hydrothermal treatment at $873 \mathrm{~K}$ for $6 \mathrm{~h}$ in 90\% water vapor atmosphere. The M-200(274)-HT catalyst exhibited well-preserved MOR structure (Fig. S11(a)) but decreased amount of hydroxyl nests indicated by intensity decrease of $3500 \mathrm{~cm}^{-1}$ band (Fig. S11(b)), showing longer life- 

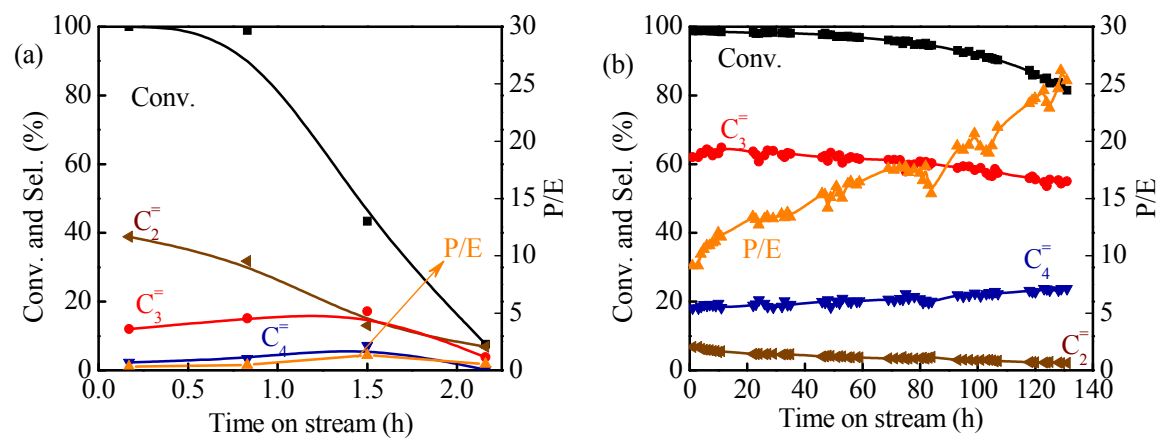

Fig. 5. Methanol conversion and the product selectivities as a function of time on stream over M-200(6) (a) and M-200(274) (b). Reaction conditions: catalyst, $0.1 \mathrm{~g}$; WHSV = $1 \mathrm{~h}^{-1}$; temperature, $723 \mathrm{~K}$; $\mathrm{N}_{2}$ gas flow rate, $20 \mathrm{~mL} \mathrm{~min}^{-1}$.

time (> $300 \mathrm{~h}$ ) with similar high propylene selectivity $(\sim 63 \%)$ in comparison to the pristine M-200(274) catalyst (Fig. S12). This indicated the potential application of highly dealuminated mordenite as selective MTP catalyst in industrial MTP process.

Besides the catalyst stability, the $\mathrm{Si} / \mathrm{Al}$ ratio significantly affected the product selectivity for the MTP reaction. The selectivity towards propylene, butylene and non-aromatic products with carbon numbers $>4\left(\mathrm{C}_{5}{ }^{\mathrm{N}}\right)$ increased with the increase of $\mathrm{Si} / \mathrm{Al}$ ratio, while the formation of ethylene, $\mathrm{C}_{1-4}$ alkanes and aromatics are significantly suppressed (Table 2). The selectivity of ethylene and propylene over M-200(6) sample was 38.9\% and $12.0 \%$, respectively. After dealumination, the propylene became the major product in lower olefins, reaching a selectivity of $63.9 \%$ for M-200(436). Interestingly, a very good linear relationship was observed between propylene selectivity and the $A_{12 \mathrm{MR}} / A_{\mathrm{F}}$ ratio (Fig. $6(\mathrm{a})$ ), suggesting the vital role of $\mathrm{Al}$ atoms in 12-MR pore in producing propylene. The corresponding $\mathrm{P} / \mathrm{E}$ ratio increased from 0.3 to 11.6 with the increase of $\mathrm{Si} / \mathrm{Al}$ ratio from 6 to 436. Meanwhile, the butylene selectivity increased from $2.3 \%$ to $18.5 \%$. The $\mathrm{C}_{2-4}=$ selectivity was $>87 \%$ for the high-silica MOR catalysts. By comprehensively considering the lifetime, propylene selectivity and P/E ratio (Fig. 6(b)), the M-200(274) catalyst showed the most outstanding performance in the MTP reaction.

\subsubsection{Effects of reaction parameters and hydrothermal} treatment on the MTP catalytic performance over M-200(274)

As M-200(274) exhibited the excellent performance in MTP reaction, the effect of reaction temperature was further inves- tigated over this catalyst in the range of 623-773 K (Fig. 7(a) and Table S3). As the temperature raised from 623 to $723 \mathrm{~K}$, the methanol conversion showed minor change within the range of $94.4 \%-98.7 \%$. In contrast, the total selectivity to ethylene and propylene increased from $51 \%$ to $69.5 \%$, while the $\mathrm{P} / \mathrm{E}$ ratios decreased from 25.8 to 11.0 , and the $\mathrm{C}_{4}=$ and $\mathrm{C}_{5+} \mathrm{N}$ selectivities obviously decreased. At higher reaction temperatures, the methylation of oligomers and further cracking to light olefins are presumed to be promoted [49], easily leading to higher selectivity of ethylene and propylene. However, further raising the reaction temperature to $773 \mathrm{~K}$, the selectivity of propylene dropped to $57.2 \%$, and the ethylene and aromatics selectivity increased to $10.8 \%$ and $6.5 \%$, respectively, probably due to the enhancement of aromatics-based cycle at high temperature ( $>723 \mathrm{~K}$ ) according to the similar results reported by Xu et al. [50].

Fig. 7(b) and Table S4 display the catalytic performance of $\mathrm{M}-200(274)$ in MTP reaction at $723 \mathrm{~K}$ by varying the weight space velocity in the range of 0.5 to $4 \mathrm{~h}^{-1}$. The methanol conversion was maintained at the same level of $98.3 \%-99.7 \%$ when weight space velocity increased from 0.5 to $4 \mathrm{~h}^{-1}$. The selectivity of propylene showed slight decrease from $64 \%$ (0.5 $\left.\mathrm{h}^{-1}\right)$ to $56.2 \%\left(4 \mathrm{~h}^{-1}\right)$. The ethylene selectivity decreased also from $7.2 \%\left(0.5 \mathrm{~h}^{-1}\right)$ to $5.4 \%\left(4 \mathrm{~h}^{-1}\right)$, while the $\mathrm{P} / \mathrm{E}$ ratio did not show significant change. Meanwhile, the selectivity of $\mathrm{C}_{4+}$ hydrocarbon and aromatics was increased at higher weight space velocity. This may be caused by the lowered cracking activity due to the shortened contact time of methanol with catalyst.

Table 2

The product distribution in the MTP reaction over the M-200(x) samples.

\begin{tabular}{|c|c|c|c|c|c|c|c|c|c|c|c|c|}
\hline \multirow{2}{*}{ Catalyst } & \multirow{2}{*}{$\begin{array}{c}\mathrm{MeOH} \\
\text { conv. (\%) }\end{array}$} & \multirow{2}{*}{$\mathrm{P} / \mathrm{E}$ ratio } & \multirow{2}{*}{ HTI } & \multirow{2}{*}{ ethylene/2MBu } & \multicolumn{7}{|c|}{ Product selectivity (\%) } & \multirow[b]{2}{*}{$\mathrm{C}_{2-4}=$} \\
\hline & & & & & $\mathrm{CH}_{4}$ & $\mathrm{C}_{2-4^{0}}$ & $\mathrm{C}_{2}=$ & $\mathrm{C}_{3}=$ & $\mathrm{C}_{4}=$ & $\mathrm{C}_{5^{+}} \mathrm{N}$ & Ar. & \\
\hline M-200(6) & 100 & 0.3 & 0.40 & 129.7 & 32.8 & 12.8 & 38.9 & 12.0 & 2.3 & 0.3 & 0.9 & 53.2 \\
\hline M-200(51) & 100 & 3.7 & 0.38 & 8.6 & 12.2 & 6.0 & 12.2 & 44.9 & 10.0 & 4.8 & 9.9 & 67.1 \\
\hline M-200(98) & 100 & 6.0 & 0.14 & 6.0 & 2.1 & 4.0 & 9.8 & 58.2 & 16.1 & 5.1 & 4.7 & 84.1 \\
\hline M-200(171) & 99.1 & 9.5 & 0.13 & 2.9 & 0.7 & 3.9 & 6.7 & 62.6 & 17.6 & 7.9 & 0.6 & 86.9 \\
\hline M-200(274) & 98.9 & 10.9 & 0.08 & 2.3 & 0.5 & 2.9 & 6.2 & 63.2 & 18.6 & 8.0 & 0.6 & 88.0 \\
\hline M-200(436) & 98.9 & 11.6 & 0.08 & 2.1 & 0.5 & 2.7 & 5.5 & 63.9 & 18.5 & 8.6 & 0.3 & 87.9 \\
\hline
\end{tabular}

Reaction conditions: catalyst, $0.1 \mathrm{~g}$; WHSV $=1 \mathrm{~h}^{-1}$; temperature, $723 \mathrm{~K}$; $\mathrm{N}_{2}$ gas flow rate, $20 \mathrm{~mL} \mathrm{~min}^{-1}$; TOS $=10 \mathrm{~min}$ for M-200(6) sample, TOS = $2 \mathrm{~h}$ for other samples; $\mathrm{C}_{5^{\mathrm{N}}} \mathrm{N}$ : non-aromatic products with carbon numbers greater than 4; Ar.: aromatics; HTI: hydrogen transfer index $\left(\mathrm{C}_{4}{ }^{0} / \mathrm{C}_{4}=\right)$; ethylene/2MBu: the ratio of ethylene to sum of 2-methylbutane and 2-methyl-2-butene. 

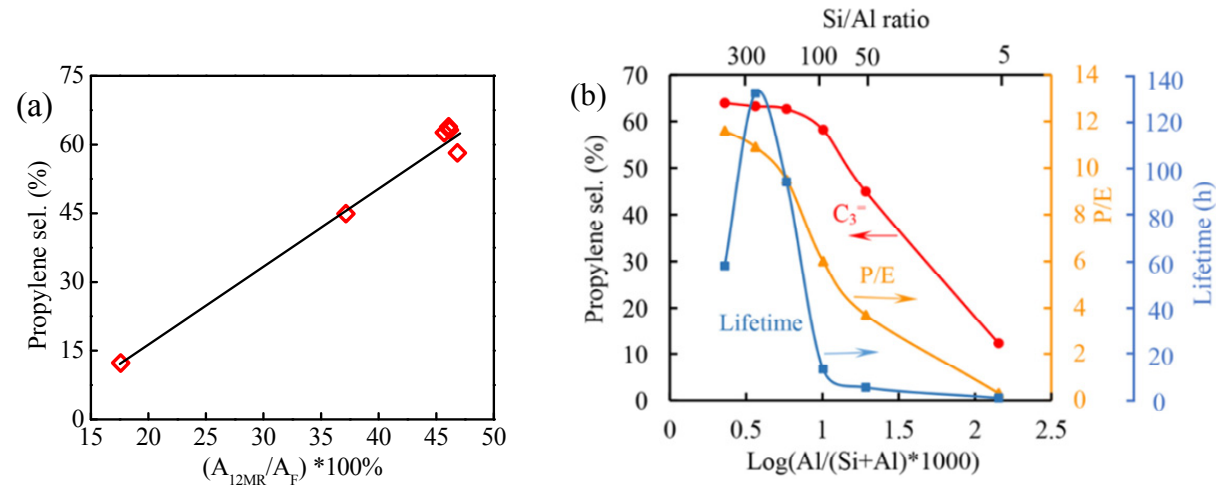

Fig. 6. (a) Dependence of propylene selectivity on the relative percentage of $\mathrm{Al}$ ions in 12-MR vs. the total Al ions; (b) Dependence of propylene selectivity, $\mathrm{P} / \mathrm{E}$ ratio and MTP lifetime on the $\mathrm{Al}$ content. The propylene selectivity and $\mathrm{P} / \mathrm{E}$ ratio were obtained at TOS $=2 \mathrm{~h}$, while the lifetime is defined as the time period with methanol conversion over $80 \%$. Reaction conditions: catalyst, $0.1 \mathrm{~g}$; WHSV = $1 \mathrm{~h}^{-1}$; temperature, $723 \mathrm{~K}$; $\mathrm{N}_{2}$ gas flow rate, $20 \mathrm{~mL}$ $\min ^{-1}$.
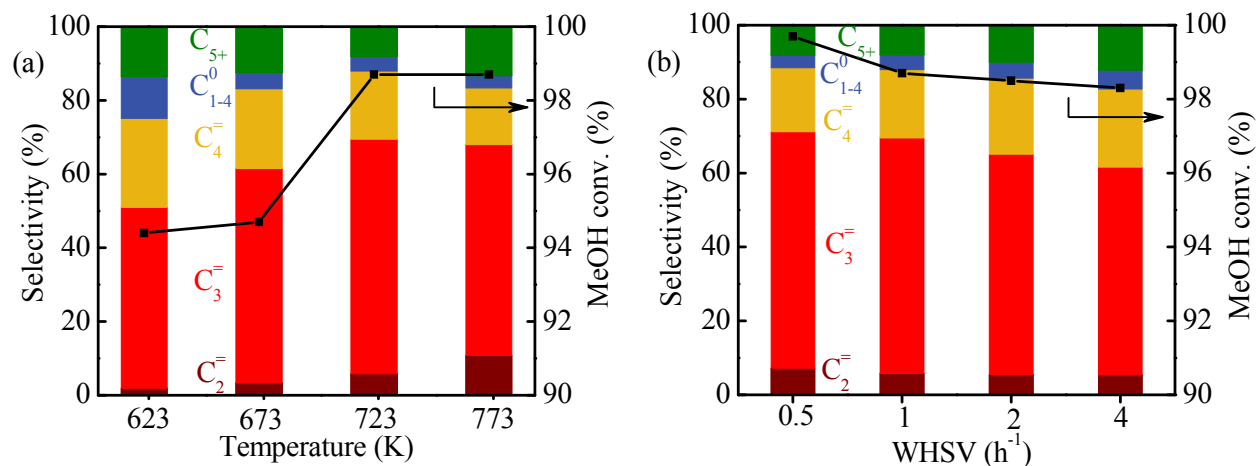

Fig. 7. Methanol conversion and product selectivity as a function of reaction temperatures (a) and weight space velocities (b) over M-200(274) catalyst. Reaction conditions: catalyst, $0.1 \mathrm{~g}$; $\mathrm{N}_{2}$ gas flow rate, $20 \mathrm{~mL} \mathrm{~min}^{-1}$; (a) WHSV = $1 \mathrm{~h}^{-1}$; (b) temperature, $723 \mathrm{~K}$.

\subsubsection{Effects of MOR crystal size on the MTP performance}

One of the intriguing issues in zeolite catalysis is that the activity, selectivity and stability are closely related to the diffusion and mass transfer of the reactants or intermediates, which is highly depended on the pore structures of zeolites and/or their crystal size. Hence we studied the influence of the crystal size of MOR on MTP reaction by keeping the $\mathrm{Si} / \mathrm{Al}$ ratios in a similar range of 150-200. In this regard, three samples with the average crystal diameters about 50, 200 and $400 \mathrm{~nm}$ were prepared and the samples were dealuminated to achieve similar Si/Al ratio. The SEM images shown in Fig. S13 indicate that the M-200 and M-400 samples possessed a prism-like shape, while the M-50 sample owned a granular-like morphology. Additionally, a rod-shape MOR catalyst with the size of 50-100 $\mathrm{nm}$ in diameter and $500-800 \mathrm{~nm}$ in length was also prepared. The XRD patterns confirmed that these samples were highly crystalline MOR phase free of any impurity (Fig. S14). The intensity of the reflection peaks decreased and the peak width became broad for M-50(154) due to the nanoscale crystal size. Compared with the XRD patterns of M-200(170) and $M-400(190)$, the intensities of 110, 020, 200, 310, 330, 150 and 350 reflections decreased for M-R(196). This is probably resulted from the preferential crystal growth along $c$-axis or the decreased crystal sizes along $a$ - and $b$-axes [36]. The SEM images indicated the crystal length along the $c$-axis of MOR topology, that is the running direction of the 12-MR main pore channels, was in the order of $\mathrm{M}-\mathrm{R}(196)>\mathrm{M}-400(190)>$ $M-200(170)>M-50(154)$. The textural properties of these sample are present in Fig. S15 and Table S5. The M-200(171) and M-50(154) samples with smaller size exhibited larger mesoporous volume up to $0.18 \mathrm{~cm}^{3} \mathrm{~g}^{-1}$ attributed to the intercrystal mesopores formed by the stacking of nanocrystals. The mesopore volume of M-400(190) and M-R(196) with larger crystal sizes was close to $0.06 \mathrm{~cm}^{3} \mathrm{~g}^{-1}$. $\mathrm{NH}_{3}$-TPD results suggest that the crystal sizes did not affect the acidity of the samples with comparable $\mathrm{Si} / \mathrm{Al}$ ratios (Fig. S16).

The catalytic results of the four samples in the MTP reaction at $723 \mathrm{~K}$ are presented in Table 3. Very similar methanol conversion (> 98\%) and product distribution were observed for all the samples at the initial stage. The selectivity towards $\mathrm{C}_{2-4}=$ over all samples were also quite similar, although the crystal length along $c$-axis differed with each other. In contrast, distinct catalytic lifetime was observed for the samples with different crystal length along $c$-axis (Fig. 8). We herein define the lifetime by the TOS time when the methanol conversion dropped below $80 \%$. M-50(154) with the smallest crystal size showed the unexpected shortest lifetime of $10 \mathrm{~h}$, while M-200(171) showed 
Table 3

The product distribution in the MTP reaction over the MOR zeolites with different morphologies at comparable $\mathrm{Si} / \mathrm{Al}$ ratios.

\begin{tabular}{|c|c|c|c|c|c|c|c|c|}
\hline \multirow{2}{*}{ Catalyst } & \multirow{2}{*}{$\begin{array}{c}\mathrm{MeOH} \\
\text { conv. (\%) }\end{array}$} & \multirow{2}{*}{$\begin{array}{l}\mathrm{P} / \mathrm{E} \\
\text { ratio }\end{array}$} & \multicolumn{6}{|c|}{ Product selectivity (\%) } \\
\hline & & & $\mathrm{C}_{1-4^{0}}$ & $\mathrm{C}_{2}=$ & $\mathrm{C}_{3}=$ & $\mathrm{C}_{4}=$ & $\mathrm{C}_{5+}{ }^{\mathrm{N}}$ & Ar. \\
\hline M-50(154) & 98.5 & 9.9 & 4.7 & 5.8 & 57.2 & 20.4 & 11.4 & 0.5 \\
\hline M-200(171) & 99.1 & 9.5 & 4.7 & 6.7 & 62.6 & 17.5 & 7.9 & 0.6 \\
\hline$M-400(190)$ & 98.8 & 11.1 & 2.2 & 5.7 & 63.4 & 19.1 & 8.9 & 0.7 \\
\hline$M-R(196)$ & 99.3 & 10.0 & 3.8 & 6.2 & 62.6 & 18.1 & 8.8 & 0.5 \\
\hline
\end{tabular}

Reaction conditions: catalyst, $0.1 \mathrm{~g}$; WHSV $=1 \mathrm{~h}^{-1}$; temperature, $723 \mathrm{~K}$; $\mathrm{N}_{2}$ gas flow rate, $20 \mathrm{~mL} \mathrm{~min}^{-1}$. $\mathrm{C}_{5+} \mathrm{N}^{\mathrm{N}}$ non-aromatic products with carbon numbers greater than 4; Ar.: aromatics.

the longest lifetime of about $100 \mathrm{~h}$. Further increasing the crystal length of $c$-axis resulted in shortened lifetime. These results suggest that an optimal crystal diameter is preferred for a selective MTP reaction over mordenite catalysts.

3.4. Comprehensive discussion on the relationship between the textural properties and catalytic performance of MOR catalysts in MTP reaction

The catalytic performances of various MOR zeolites suggest that the MTP behavior can be comprehensively affected by the porosity, Al location and acid density and strength. Dealuminated MOR exhibited higher selectivity and was more stable for MTP reaction, compared to the pristine low-silica MOR catalyst. The dealumination changed the porosity and acid properties of MOR material. For instance, the external surface area of M-200 increased by 5 times upon dealumination and its mesoporous volume also increased from 0.08 to $0.18 \mathrm{~cm}^{3} \mathrm{~g}^{-1}$ when the $\mathrm{Si} / \mathrm{Al}$ ratio was raised from 6 to 171 . Both the calcination and acid leaching in the dealumination process are of great importance in enhancing the external surface area and mesopore volume. The calcination expels the aluminum atoms from the framework of the parent mordenite, forming $\mathrm{Al}_{2} \mathrm{O}_{3}$ aggregates and some mesopores. However, these extra framework $\mathrm{Al}\left(\mathrm{Al}_{2} \mathrm{O}_{3}\right.$ aggregates) could block the pore channels of the parent mordenite material according to previous report [51]. Thereafter, the acid leaching is helpful to remove these extra framework $\mathrm{Al}$ species as well as some framework $\mathrm{Al}$ atoms. The evolution of Al species was firmly supported by the ${ }^{27} \mathrm{Al}$ MAS NMR results (Fig. S3). In addition, the dealumination slightly enlarges the size of 12-MR as revealed by the pore size distribution curves calculated by the Ar sorption isotherms (Fig. S2). Therefore, the dealumination process modifies the porosity of mordenite, greatly improving the mass transport and facilitating the desorption of products. Another experimental phenomenon related to the diffusion issue is that the catalytic performance shows a crystal-size dependent behavior. The M-R(196) sample having the longest crystal length along $c$-axis retards the diffusion of the products and then promotes the side reactions to induce fast deactivation and greatly shortened lifetime.

The location of Al atoms significantly affected catalytic performance of MOR catalyst in the MTP reaction. The dealumination process selectively removed the $\mathrm{Al}$ atoms located in $\mathrm{T} 1$ and $\mathrm{T} 3$ sites and those $\mathrm{Al}$ atoms in $\mathrm{T} 2$ and/or T4 sites (shared by the 8-MR side pockets and 12-MR pores) were intact. Pyridine, as a alkaline molecule, can selectively adsorb on the acid sites in pores with large-enough size, thus selectively poisoning the BA sites in open reaction spaces, for instance the 12-MR pores in MOR structure. This could be employed to identify the location of the residual $\mathrm{Al}$ atoms after dealumination. Fig. S17 compares the catalytic performances of M-200(274) for MTP in the absence or in the presence of poisoning agent pyridine. When 1300 ppm of pyridine was co-fed with methanol into the catalyst bed, the methanol conversion reached $95 \%$ in the initial $10 \mathrm{~min}$ and then rapidly declined to $2 \%$ at the TOS of 70 min, with alkanes as the main products. The acid sites in the dealuminated MOR catalyst of M-200(274) was completely deactivated by introducing pyridine, meaning that these $\mathrm{Al}$ atoms were accessible to pyridine. Taking into account of the Py-IR and other characterization results descried above (Fig.
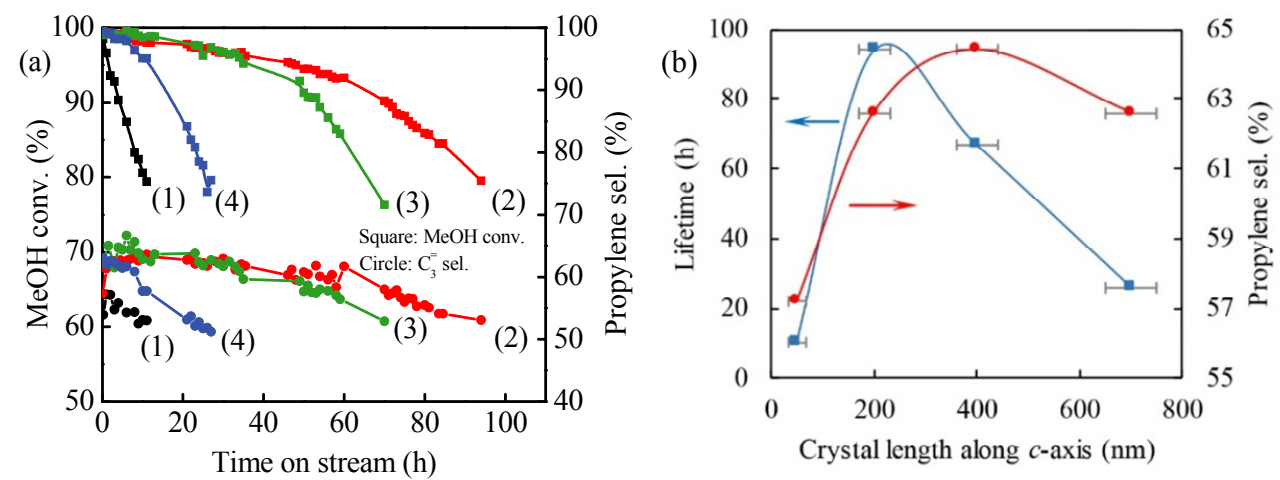

Fig. 8. (a) Methanol conversion and propylene selectivity as a function of TOS over M-50(154) (1), M-200(171) (2), M-400(190) (3) and M-R(196) (4) (b) The propylene selectivity (TOS $=2 \mathrm{~h}$ ) and the lifetime as a function of the crystal length along $c$-axis. Reaction conditions: catalyst, $0.1 \mathrm{~g}$; WHSV = 1 $\mathrm{h}^{-1}$; temperature, $723 \mathrm{~K}$; $\mathrm{N}_{2}$ gas flow rate, $20 \mathrm{~mL} \mathrm{~min}^{-1}$. 
S7), we can safely deduce that these residual Al atoms are located in the intersection between 8-MR side pockets and 12-MR channels. With the increase of relative percentage of $\mathrm{Al}$ atoms in T2 and/or T4 sites, the selectivity of propylene and butylene increased, while the selectivity of ethylene decreased (Fig. 6(a) and Fig. S18), indicating that the Al atoms located in $\mathrm{T} 2$ and/or T4 shared by the 8-MR side pockets and 12-MR channels are critical in catalyzing the MTP reaction through the olefin-cycle, and then favor the production of propylene and butylene. This special Al location in open space is also beneficial to the diffusion of products and intermediates, and results in longer lifetime for high-silica MOR zeolites due to the suppressed coke deposition [52,53]. This observation, together with our recent study on the selective ethylene production over MOR nanosheet with highly accesiable 8-MR pore windows [11], leads to a full understanding on the relationship of Al location and product distribution in mordenite.

Another possible reason responsible for the excellent performance of dealuminated MOR could be related to the low acid density and strength. According to the hydrocarbon pool mechanism, the low acid density and strength may change the reaction mechanism from aromatic-based cycle to olefin-based cycle [16,54-58]. This change is also beneficial to longer lifetime, the production of higher alkenes and higher $\mathrm{P} / \mathrm{E}$ ratio. Meanwhile the hydrogen transfer index ( $\mathrm{HTI}=\mathrm{C}_{4}{ }^{0} / \mathrm{C}_{4}=$ ), as an indicator to assess hydrogen transfer activity of the transformation of olefins, also decreased with the decrease of acid density (Table 2). Moreover, the strong acid sites in low-silica MOR, for instance M-200(6), result in a high yield of methane about $32.8 \%$ via the hydrogen transfer on the $\mathrm{Al}$ sites at the initial reaction stage [51]. In contrast, much lower methane selectivity ( $<1 \%)$ was observed for high-silica MOR catalysts. This indicates the descending acid density suppresses the side reactions in methanol conversion and the dealumination process removes those $\mathrm{Al}$ acid sites for undesired reactions in MTP reaction.

To shed light on how the dealumination process affects the reaction mechanism, we have tried to extract the reaction intermediates at the initial period with TOS of $2 \mathrm{~min}$. Two samples, i.e. M-200(6) and M-200(274) were chosen because M-200(6) showed the shortest lifespan while M-200(274) showed the longest lifetime. For M-200(6), after reaction for 2 min at $623 \mathrm{~K}$, the sample was quenched and the trapped organic species were extracted and analyzed by GC-MS (Fig. 9(1)). Several polymethylbenzenes with two to six methyl groups and large amount of bulky molecules such as polymethylnaphthalenes were detected. It is quite possible that the micropores are blocked by these bulky polymethylnaphthalenes thus leading to decreased micropore volume (Table S6) and short lifetime [13]. When using M-200(274) as the catalyst, the methanol conversion at $623 \mathrm{~K}$ led to the formation of certain amount of methylbenzenes with four to six methyl groups (Fig. 9(2)), which are thought to be the major aromatic intermediates for propylene production according to the aromatic cycle. It should be emphasized that only trace bulky compounds were found in this case. Increasing the reaction temperature to $723 \mathrm{~K}$, traces of organics were observed due to the enhancement of the diffusion at higher temperature. It is worthy of noting that very small amount of aromatics was detected by GC in the effluent with the reaction temperature increased from 623 to $723 \mathrm{~K}$. This result may suggest that the contribution of aromatics-based cycle to the reaction is rather minor for the M-200(274) sample. This assumption can be also supported by the ethylene/2MBu ratio (the ratio of ethylene to the sum of 2-methylbutane and 2-methyl-2-butene), which is used to assess the relative propagation of aromatics- and olefins-based cycles [59]. The ethylene/2MBu ratio decreased dramatically from 129.7 for the M-200(6) catalyst to 2.3 for M-200(274) catalyst (Table 2), suggesting that the enhancement of olefins-based cycle with increasing the $\mathrm{Si} / \mathrm{Al}$ ratios. Therefore, the olefins-based cycle is dominating for the M-200(274) catalyst in converting methanol to propylene at $723 \mathrm{~K}$ and the reaction mechanism is proposed in Scheme 2.

It is worth noting that the aromatic-based cycle is favored for the M-200(6), while the selectivity of aromatics over $\mathrm{M}-200(6)$ is very low. The acid density and strength of the M-200(6) were higher than those of the dealuminated MOR samples (Fig. S8), which induced fast conversion of the aromatics into bulky molecules and coke occluded inside the micropores of MOR zeolite, as revealed by the GC-MS results (Fig. 9(1) and Fig. $\mathrm{S} 19(\mathrm{a})$ ) after being extract by $\mathrm{CH}_{2} \mathrm{Cl}_{2}$. Thus, only very few aromatics were detected by GC in the effluent for the M-200(6) sample. In contrast, only trace bulky molecules were observed in the dealuminated MOR sample at the initial reaction stage (Figs. 9(2) and (3)). The higher coke formation rate of the M-200(6) than that of dealumianted MOR (Fig. S10) also proved the fast conversion of the aromatics into bulky molecules and coke in the case of M-200(6). Meanwhile, hydrogenolysis reactions between methanol and polycyclic aromatics in M-200(6) generated large amount of methane leading to the high methane selectivity [60-62]. This observation is consistent with the shorter life span of MOR with low Si/Al ratio.

To further determine the location of coke, a two-step extraction process was performed. As shown in Fig. S19, almost all polycyclic aromatics (coke precursors) located in the

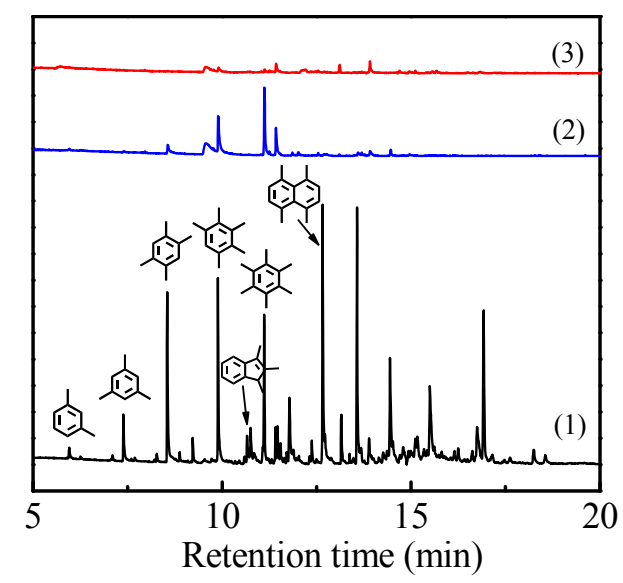

Fig. 9. GC-MS chromatograms of the hydrocarbon species retained on various used M-200 catalysts after MTP reaction at different temperature at TOS of 2 min. (1) M-200(6), $623 \mathrm{~K}$; (2) M-200(274), $623 \mathrm{~K}$; (3) $\mathrm{M}-200(274), 723 \mathrm{~K}$. The MTP reaction conditions: catalyst, $0.1 \mathrm{~g}$; WHSV $=1 \mathrm{~h}^{-1} ; \mathrm{N}_{2}$ gas flow rate, $20 \mathrm{~mL} \mathrm{~min}^{-1}$. 


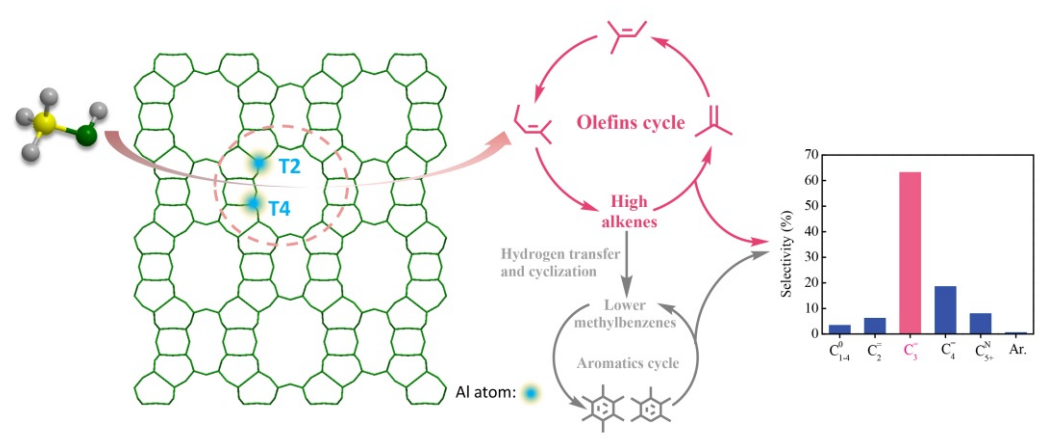

Scheme 2. The reaction mechanism of the methanol to propylene over the dealumianted mordenite catalyst.

micropores of M-200(6) and M-200(274) catalyst. Very few organic species on the surface and pore mouth were observed for M-200(6) sample, while no organic species were detected on the surface and pore mouth for M-200(274) sample. Considering the space limitation of 8-MR channels, the 8-MR channel is difficult to accommodate large intermediates [63]. Thus, we speculate that most of the coke located in 12-MR channels.

\section{Conclusions}

In summary, dealuminated mordenite zeolites with ultra-high Si/Al ratios of $>200$ show an outstanding performance in the MTP process. The dealumination process markedly affects the catalytic performance of MOR catalyst in MTP reaction, via reducing the Brönsted acidity, modifying the porosity and adjusting the location of aluminum atoms. When the $\mathrm{Si} / \mathrm{Al}$ ratio was $>98$ after dealumination, only the $\mathrm{Al}$ atoms in $\mathrm{T} 2$ and/or T4 sites are left in the framework, both of which are located in the intersection of 8-MR side pockets and 12-MR pore. The lower acid density and strength weaken the aromatics-based cycle and enhance the olefins-based cycle, and the isolated $\mathrm{Al}$ sites in the 12-MR pores favor the mass transport and suppress the coking rate, leading to high propylene selectivity $(\sim 63 \%)$ and stability. The preliminary study on the morphology suggest that the crystal size does not affect the propylene selectivity but significantly influence the catalyst lifetime. Mordenite with an optimum size of $\sim 200 \mathrm{~nm}$ afford the longest lifetime for MTP reaction.

\section{Electronic supporting information}

Supporting information is available in the online version of this article.

\section{References}

[1] P. Tian, Y. Wei, M. Ye, Z. Liu, ACS Catal., 2015, 5, 1922-1938.

[2] M. Stocker, Microporous Mesoporous Mater., 1999, 29, 3-48.

[3] M. Bjorgen, S. Svelle, F. Joensen, J. Nerlov, S. Kolboe, F. Bonino, L. Palumbo, S. Bordiga, U. Olsbye, J. Catal., 2007, 249, 195-207.

[4] S. Svelle, F. Joensen, J. Nerlov, U. Olsbye, K.-P. Lillerud, S. Kolboe, M. Bjorgen, J. Am. Chem. Soc., 2006, 128, 14770-14771.

[5] S. Ilias, A. Bhan, J. Catal., 2014, 311, 6-16.
[6] W. Song, H. Fu, J. Haw, J. Am. Chem. Soc., 2001, 123, 4749-4754.

[7] M. Bjorgen, F. Joensen, K.-P. Lillerud, U. Olsbye, S. Svelle, Catal. Today, 2009, 142, 90-97.

[8] U. Olsbye, S. Svelle, M. Bjorgen, P. Beato, T. V. W. Janssens, F. Joensen, S. Bordiga, K. P. Lillerud, Angew. Chem., Int. Ed., 2012, 51, 5810-5831.

[9] J. Zhong, J. Han,Y. Wei, S. Xu, T. Sun, S. Zeng, X. Guo, C. Song, Z. Liu, Chin. J. Catal., 2019, 40, 477-485.

[10] Y. Bhawe, M. Moliner-Marin, J. D. Lunn, Y. Liu, A. Malek, M. Davis, ACS Catal., 2012, 2, 2490-2495.

[11] K. Lu, J. Huang, L. Ren, C. Li, Y. Guan, B. Hu, H. Xu, J. Jiang, Y. Ma, P. Wu, Angew. Chem. Int. Ed., 2020, 59, 6258-6262.

[12] X. Zhu, J. P. Hofmann, B. Mezari, N. Kosinov, L. Wu, Q. Qian, B. M. Weckhuysen, S. Asahina, J. Ruiz-Martinez, E. J. M. Hensen, ACS Catal., 2016, 6, 2163-2177.

[13] C. Wang, J. Xu, Q. Wang, X. Zhou, G. Qi, N. Feng, X. Liu, X. Meng, F. Xiao, F. Deng, ACS Catal., 2017, 7, 6094-6103.

[14] C. Wang, M. Yang, P. Tian, S. Xu, Y. Yang, D. Wang, Y. Yuan, Z. Liu, J. Mater. Chem. A, 2015, 3, 5608-5616.

[15] Q. Sun, N. Wang, G. Chen, X. Chen, J. Yu, J. Mater. Chem. A, 2015, 3, 19783-19789.

[16] M. Yang, B. Li, M. Gao, S. Lin, Y. Wang, S. Xu, X. Zhao, P. Guo, Y. Wei, M. Ye, P. Tian, Z. Liu, ACS Catal., 2020, 10, 3741-3749.

[17] C. Wang, J. Xu, G. Qi, Y. Gong, W. Wang, P. Gao, Q. Wang, N. Feng, X. Liu, F. Deng, J. Catal., 2015, 332, 127-137.

[18] M. Firoozi, M. Baghalha, M. Asadi, Catal. Commun., 2009, 10, 1582-1585.

[19] S. Hu, J. Shan, Q. Zhang, Y. Wang, Y. Liu, Y. Gong, Z. Wu, T. Dou, Appl. Catal. A, 2012, 445-446, 215-220.

[20] J. Liu, C. Zhang, Z. Shen, W. Hua, Y. Tang, W. Shen, Y. Yue, H. Xu, Catal. Commun., 2009, 10, 1506-1509.

[21] Z. Liu, X. Dong, Y. Zhu, A.-H. Emwas, D. Zhang, Q. Tian, Y. Han, ACS Catal., 2015, 5, 5837-5845.

[22] S. Svelle, U. Olsbye, F. Joensen, M. Bjorgen, J. Phys. Chem. C, 2007, 111, 17981-17984.

[23] X. Zhao, L. Wang, J. Li, S. Xu, W. Zhang, Y. Wei, X. Guo, P. Tian, Z. Liu, Catal. Sci. Technol., 2017, 7, 5882-5892.

[24] J. Zhang, Z. Huang, P. Li, X. Zhang, X. Zhang, Y. Yuan, L. Xu, Catal. Sci. Technol., 2017, 7, 2194-2203.

[25] J. Zhang, L. Xu, Y. Zhang, Z. Huang, X. Zhang, X. Zhang, Y. Yuan, L. Xu, J. Catal., 2018, 368, 248-260.

[26] M. Yoshioka, T. Yokoi, T. Tatsumi, ACS Catal., 2015, 5, 4268-4275.

[27] B. L. Meyers, T. H. Fleisch, G. J. Ray, J. T. MillerI, J. B. Hall, J. Catal., 1988, 110, 82-95.

[28] M. Sawa, M. Niwa, Y. Murakami, Appl. Catal., 1989, 53, 169-181.

[29] M. Sawa, K. Kato, K. Hirota, M. Niwa, Y. Murakami, Appl. Catal., 1990, 64, 297-308. 


\title{
Graphical Abstract
}

Chin. J. Catal., 2021, 42: 1147-1159 doi: 10.1016/S1872-2067(20)63726-3

Selective conversion of methanol to propylene over highly dealuminated mordenite: Al location and crystal morphology effects

Li Ren, Bowen Wang, Kun Lu, Rusi Peng, Yejun Guan*,

Jin-gang Jiang, Hao Xu *, Peng Wu *

East China Normal University

The high-silica MOR catalysts $(\mathrm{Si} / \mathrm{Al}>150)$ selectively catalyzed the methanol conversion in the methanol to propylene (MTP) way, providing a high propylene selectivity of $63 \%$ and a long lifetime of $\sim 130 \mathrm{~h}$. The excellent performance of highly dealuminated MOR is ascribed to the mesopores formed upon dealumination and the scarce $\mathrm{Al}$ sites located in the $\mathrm{T}$ sites shared by the 8-MR side pockets and 12-MR pore channels as well as the weakened acid strength.

[30] D. Rojo-Gama, S. Etemadi, E. Kirby, K. P. Lillerud, P. Beato, S. Svelle, U. Olsbye, Faraday Disc., 2017, 197, 421-446.

[31] V. R. Chumbhale, A. J. Chandwadkar, B. S. Rao, Zeolites, 1992, 12, 63-69.

[32] Y. Mao, Y. Zhou, H. Wen, J. Xie, W. Zhang, J. Wang, New J. Chem., 2014, 38, 3295-3301.

[33] A. Lv, H. Xu, H. Wu, Y. Liu, P. Wu, Microporous Mesoporous Mater., 2011, 145, 80-86.

[34] H. K. Beyer, Springer-Verlag Berlin Heidelberg, 2002.

[35] J. W. Park, S. J. Kim, M. Seo, S.Y. Kim, Y. Sugi, G. Seo, Appl. Catal. A, 2008, 349, 76-85.

[36] Y. Yang, J. Ding, C. Xu, W. Zhu, P. Wu, J. Catal., 2015, 325, 101-110.

[37] A. A. C. Reule, J. A. Sawada, N. Semagina, J. Catal., 2017, 349, 98-109.

[38] S. Ban, A. N. C. van Laak, J. Landers, A.V. Neimark, P. E. de Jongh, K. P. de Jong, T. J. H. Vlugt, J. Phys. Chem. C, 2010, 114, 2056-2065.

[39] P. Bodart, J. B. Nagy, G. Debras, Z. Gabelica, P. A. Jacobs, J. Phys. Chem., 1986, 90, 5183-5190.

[40] J. L. Schlenker, J. J. Pluth, J. V. Smith, Mater. Res. Bull., 1979, 14, 751-758.

[41] F. Wakabayashi, J. N. Kondo, K. Domen, C. Hirose, J. Phys. Chem., 1996, 100, 4154-4159.

[42] F. L. Bleken, S. Chavan, U. Olsbye, M. Boltz, F. Ocampo, B. Louis, Appl. Catal. A, 2012, 447, 178-185.

[43] D. B. Lukyanov, T. Vazhnova, N. Cherkasov, J. L. Casci, J. J. Birtill, J. Phys. Chem. C, 2014, 118, 23918-23929.

[44] O. Marie, F. Thibault-Starzyk, J. C. Lavalley, Phys. Chem. Chem. Phys., 2000, 2, 5341-5349.

[45] R. Buzzoni, S. Bordiga, G. Ricchiardi, C. Lamberti, A. Zecchina, Langmuir, 1996, 12, 930-940.
[46] C. Pazé, S. Bordiga, C. Lamberti, M. Salvalaggio, A. Zecchina, J. Phys. Chem. B, 1997, 101, 4740-4751.

[47] F. Bonino, A. Damin, S. Bordiga, C. Lamberti, A. Zecchina, Langmuir, 2003, 19, 2155-2161.

[48] M. Niwa, K. Suzuki, N. Katada, T. Kanougi, T. Atoguchi, J. Phys. Chem. $B$, 2005, 109, 18749-18757.

[49] A. J. Marchi, G. F. Froment, Appl. Catal., 1991, 71, 139-152.

[50] J. Zhang, Z. Huang, L. Xu, X. Zhang, X. Zhang, Y. Yuan, L. Xu, Catal. Sci. Technol., 2019, 9, 2132-2143.

[51] A. J. Marchi, G. F. Froment, Appl. Catal. A, 1993, 94, 91-106.

[52] V. R. Choudhary, S. Mayadevi, A. P. Singh, J. Chem. Soc. Faraday Trans., 1995, 91, 2935-2944.

[53] C. E. Webster, A. Cottone, R. S. Drago, J. Am. Chem. Soc., 1999, 121, 12127-12139.

[54] W. Dai, X. Wang, G. Wu, L. Li, N. Guan, M. Hunger, ChemCatChem, 2012, 4, 1428-1435.

[55] R. Khare, Z. Liu, Y. Han, A. Bhan, J. Catal., 2017, 348, 300-305.

[56] J. Chen, J. Li, C. Yuan, S. Xu, Y. Wei, Q. Wang, Y. Zhou, J. Wang, M. Zhang, Y. He, S. Xu, Z. Liu, Catal. Sci. Technol., 2014, 4, 3268-3277.

[57] M. Bjorgen, S. Kolboe, Appl. Catal. A, 2002, 225, 285-290.

[58] M. Westgaard. Erichsen, S. Svelle, U. Olsbye, J. Catal., 2013, 298, 94-101.

[59] S. Ilias, R. Khare, A. Malek, A. Bhan, J. Catal., 2013, 303, 135-140.

[60] J. Li, M. Liu, S. Li, X. Guo, C. Song, Ind. Eng. Chem. Res., 2019, 58, 1896-1905

[61] X. Sun, S. Mueller, H. Shi, G. L. Haller, M. Sanshez-Sanchez, A. C. V. Veen, J. A. Lercher, J. Catal., 2014, 314, 21-31.

[62] H. Schulz, Catal. Today, 2010, 154, 183-194.

[63] S. Teketel, U. Olsbye, K.-P. Lillerud, P. Beato, S. Svelle, Microporous Mesoporous Mater., 2010, 136, 33-41.

\section{脱铝丝光分子篎应用于MTP反应: AI的落位和晶体形貌的影响}

\author{
任 栋, 王博文，陆 琨，彭如斯，关业军”，蒋金刚，徐 浩\$，吴 鹏* \\ 华东师范大学化学与分子工程学院, 绿色化学与化工过程上海市重点实验室, 上海200062
}

摘要: 甲醇制烯烃/丙烯工艺(MTO/MTP)是当前煤基碳资源绿色催化转化的重要过程之一. 在MTO/MTP工艺中, 分子筛通 常面临低碳烯烃选择性低、水热稳定性差和寿命短等挑战. 开发高选择性和高稳定性的分子䇥催化剂对煤基乙烯/丙烯等 
化学品的工业生产具有重要意义. 本文选择了具有 12 元环孔道的低硅丝光分子篮 $(\mathrm{Si} / \mathrm{Al}=6)$ 为母体, 对其进行脱铝处理制 备了一系列不同 $\mathrm{Al}$ 含量的高硅丝光 $(\mathrm{Si} / \mathrm{Al}=51-436)$ 催化剂. 通过 $\mathrm{N}_{2}$-吸附、 $\mathrm{NH}_{3}$ 程序升温脱附、羟基红外光谱、 $\mathrm{CD}_{3} \mathrm{CN}-\mathrm{IR}$ 和Py-IR等技术对脱铝前后分子篮的孔道结构、酸密度、酸强度和铝的落位进行了深入研究, 并将其与MTP反应性能进行 关联. 结果表明, 骨架 $\mathrm{Al}$ 的脱除在晶体中引入了介孔. 随着 $\mathrm{Si} / \mathrm{Al}$ 的提高, 分子篮的酸量和酸强度同时降低. 深度脱铝后的 丝光分子篮中只存在少量位于8元环侧口袋与12元环交叉口处的T2和T4位A1原子.

$\mathrm{Si} / \mathrm{A} 1$ 高于 150 的脱铝丝光分子篮在MTP反应中丙烯选择性高达 $63 \%$, 丙烯/乙烯的比值高达 10 . 与低硅丝光分子篮相 比, 深度脱铝的丝光分子篮表现出更好的稳定性和更长的寿命. 相同反应条件下, 低硅丝光样品 $(\mathrm{Si} / \mathrm{Al}=6)$ 反应 $2 \mathrm{~h}$ 后完全 失活(转化率低于 $10 \%)$, 而高硅丝光样品 $(\mathrm{Si} / \mathrm{Al}=274)$ 反应 $132 \mathrm{~h}$ 后转化率仍然高于 $80 \%$. 丝光分子篮在脱铝处理后催化性能 得到大幅提升的原因为: 酸密度和酸强度的降低显著改变了双循环机理历程, 反应中芳烃循环的比重下降, 烯烃循环得到 了增强, 进而提高了丙烯选择性并抑制了积碳速率. 此外, 脱铝后保留下来的A1原子(活性中心)位于 12 元环孔道, 其大孔结 构与脱铝引入的介孔孔道为反应物、中间体及产物的扩散提供了充足的空间, 进一步抑制了副反应的发生和积碳的生成. 进一步研究丝光分子笁形貌对MTP 反应的影响发现, 丝光分子笁尺寸的变化不改变产物分布, 但显著影响催化剂寿命, 其 原因在于丝光分子篮 $c$-轴长度的增加使得烃池物种的扩散受到限制, 导致催化剂的寿命降低.

关键词: 丝光分子筛; 甲醇制丙烯; 脱铝; Al落位; 晶粒尺寸

收稿日期: 2020-09-05. 接受日期: 2020-10-10. 上网时间: 2021-03-05.

*通讯联系人. 电话/传真: (021)62232292; 电子信箱: pwu@chem.ecnu.edu.cn

\#通讯联系人. 电子信箱: yjguan@chem.ecnu.edu.cn

通讯联系人. 电子信箱: hxu@chem.ecnu.edu.cn

基金来源：国家重点研发计划(2016YFA0202804); 国家自然科学基金(21533002，21872052，21972044); 中央高校基本科研业务 费专项资金资助.

本文的电子版全文由Elsevier出版社在ScienceDirect上出版(http://www.sciencedirect.com/journal/chinese-journal-of-catalysis). 